\title{
Microbiological and Water Quality Status of Cibanten River
}

\author{
Fauzul Hayat* \\ Public Health \\ Faletehan University \\ Serang, Indonesia \\ fauzulhayat@yahoo.co.id
}

\author{
Nia Kurniatillah \\ Public Health \\ UNBAJA University \\ Serang, Indonesia \\ kurniatillah02@gmail.com
}

\begin{abstract}
The Cibanten river is very important for life aquatic organisms and human survival. The purpose of this study was to determine the water quality status and microbiological analyses involved Total Coliform (TC) and estimation of Fecal Coliform (FC) of Cibanten river. Water sampling was conducted along by Cibanten river from up to downstream at six (6) stations for a period from March-October 2017. The number of total and faecal coliform was analysed using the Most Probable Number (MPN) method and STORET method for determining water quality status. Total coliform counts varied from $2400-9200 \mathrm{MPN} / 100 \mathrm{ml}$. The maximum total coliform is found in upstream of station 1 (Pabuaran village) $9200 \mathrm{MPN} / 100 \mathrm{ml}$ was recorded in March-May 2017. Fecal coliform counts varied from 1300-6400 MPN/100 ml. The maximum fecal coliform is found in station 1 (Pabuaran village) $6300 \mathrm{MPN} / 100 \mathrm{ml}$ was recorded in August-October 2017. Based on STORET method showed that water quality of Cibanten river in moderately polluted. In some situations, even stricter requirements and policies are necessary to achieve sustainability of water quality and ecology in Banten Province.
\end{abstract} status

Keywords-microbiological, Cibanten rivers, water quality

\section{INTRODUCTION}

The Cibanten river flows from Karang mountain Pandeglang pass through Serang district with river length is $35.89 \mathrm{~km}$. The Cibanten river is very important for life aquatic organisms and human survival. [1] The Cibanten river serves to support sustainable development and to support economic growth in the urban and industrial areas. Increased settlement activities along the river banks, exploitation of agricultural land and the poor living behavior of the people that produce domestic waste make the pollutant burden in Cibanten river.[2]

Water contamination with pathogenic microorganisms represents a seriously increased threat to human health. [3] Fecal pollution is the major cause of waterborne disease, since most of the pathogens associated with transmission reside in human and warm-blooded animal faeces. [4] Water borne diseases reported such as diarrhoea, typhoid fever and bacillary dysentery normally result from infections by pathogenic microbes, which implies the microbial pollution has an effect on public health. [5] At present, the most widely used water quality indicators include Escherichia coli, total and fecal coliforms, as well as intestinal Enterococci [6]. The assessment of microbiological water quality should aim to protect human beings from illness due to the consumption of water that may contain pathogens contributing to waterborne disease.[3] Determine influential water quality factors affecting the concentration of coliform bacteria at Cibanten river analyses in order to ultimately lay a foundation for efficient future water quality management.

\section{METHOD}

\section{A. Water sampling stations}

Water sampling was conducted along the Cibanten river from up to downstream at six (6) stations: Pabuaran village (Station 1), Telaga kencana (Station 2), Sumber abadi (Station 3), Kampung serut (Station 4), Kaujon bridge (Station 5), Kaibon bridge (Station 6). Grab sampling procedure was adopted as recommended by standard method for microbiological analyses. [7]

\section{B. MPN method}

The number of total and fecal coliform was determined using the most probable number (MPN) method using the double tube method. In the double tube method, the three basic steps to detect the presence of coliform bacteria in water are presumptive, confirmed and completed tests. The tests are performed sequentially on each sample.

Presumptive coliform test: Inoculation on lactose broth medium. Five broth tube series the first series containing five double strength broth tubes and the remaining two series comprising 10 single strength broth tubes were inoculated with $10 \mathrm{ml}, 1 \mathrm{ml}$, and $0.1 \mathrm{ml}$ of water (ratio 5:5:5), respectively. If there is bubble formation, continue to confirm the test. [8,9]

Confirmed test: Inoculation on brilliant green bile lactose broth (BGLB). To calculate the total coliform, the inoculated BGLB tubes were incubated at $35 \pm 0.5^{\circ} \mathrm{C}$ for 48 hours, while for fecal coliform, the inoculated BGLB tubes were incubated at $44.5 \pm 0.2^{\circ} \mathrm{C}$ for 48 hours. Calculate the MPN of coliform based on the proportion of confirmed gassing in BGLB tubes for 5 consecutive dilutions. [8,9]

The MPNs at different sampling locations were tabulated and compared to the MPNs in requirement of water quality status based on [10] Government regulation No. 82 of 2001 concerning the management of water quality and water pollution control. (Table 1). 
TABLE I. CLASSIFICATION OF MiCROBIOLOGICAL StATUS

\begin{tabular}{lcccc}
\hline \multirow{2}{*}{ Microbiological } & \multicolumn{4}{c}{ Class } \\
\cline { 2 - 5 } & I & II & III & IV \\
\hline Fecal coliform (count/100 ml) & 100 & 1000 & 2000 & 2000 \\
Total coliform (count/100 m) & 1000 & 5000 & 10000 & 10000 \\
\hline
\end{tabular}

\section{STORET method}

STORET methods for water quality status. Data were analysis based on STORET as well as Indonesia Government regulation No. 82/2001 (class II), water quality of infrastructure, water recreation facilities, freshwater fish culture, animal husbandry, and irrigation on Cibanten river.[11]

STORET is intended to point out contamination level (Minister of Environment Decree No. 115/2003). [8] STORET is determined for a particular purpose (class II). Determination of criteria is based on the score at Table 2 .

TABLE II. STORET SCORE AND WATER QUALITY STATUS

\begin{tabular}{cll}
\hline Class & \multicolumn{1}{c}{ Score } & \multicolumn{1}{c}{ Status } \\
\hline A & 0 & Meet quality standards \\
B & -1 to -10 & Slightly polluted \\
C & -11 to -30 & Moderately polluted \\
D & $<-30$ & Heavily polluted \\
\hline
\end{tabular}

\section{RESUlTS AND DISCUSSION}

\section{A. Microbiological count}

Microbiological analyses involved Total Coliforms (TC) and estimation of Fecal Coliforms (FC). The results of total coliform found fluctuations both upstream and downstream at six monitoring site along the Cibanten river. Total coliform counts varied from 2400-9200 MPN/100 ml. The maximum total coliform is found in upstream of station 1 (Pabuaran village) 9200 MPN/100 ml was recorded in March-May 2017. The results of the total coliform are shown in (Figure.1). Fecal coliform counts varied from 1300-6400 NPM/100 ml. The maximum fecal coliform is found in station 1 (Pabuaran village) $6300 \mathrm{MPN} / 100 \mathrm{ml}$ was recorded in August-October 2017. The results of the total coliform are shown in (Figure.2). This might be explained by the effect of domestic, agricultural and industrial waste disposal from the urbanized surrounding area. [9] Water borne diseases reported such as diarrhoea, typhoid fever and bacillary dysentery normally result from infections by pathogenic microbes, which implies the microbial pollution has an effect on public health.[4] In general, the water in Cibanten river is not recommended to be used as drinking water. However, the result using microbiology parameters showed that the water still can be used as clean water, but more the water treatment needed to produce clean water.

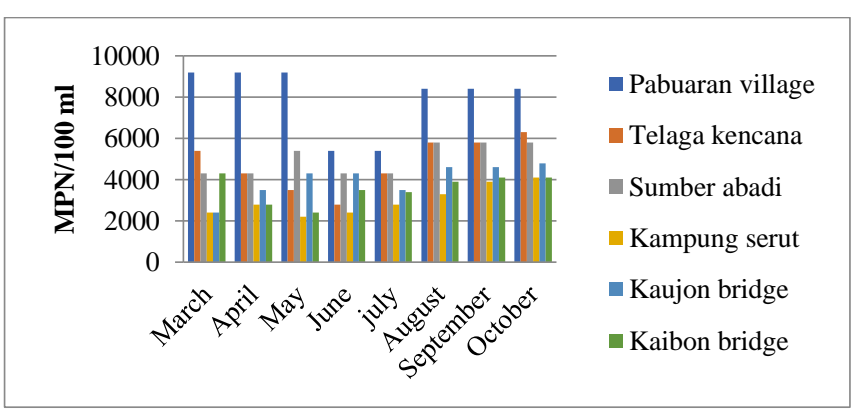

Fig. 1. Total coliform for each sampling sites.

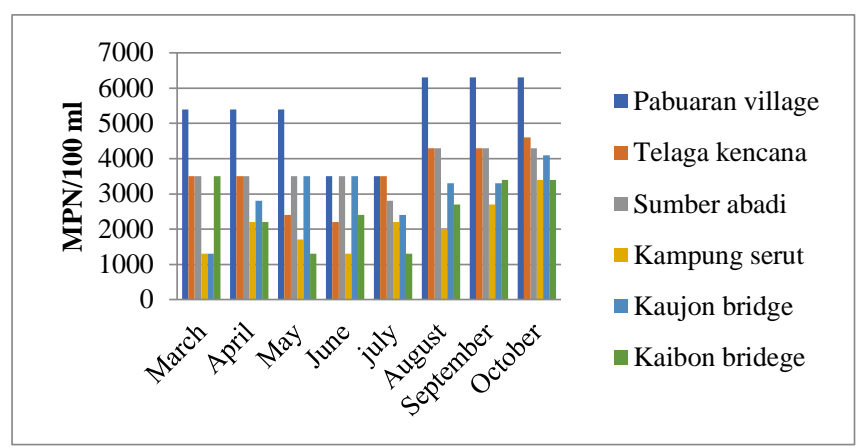

Fig. 2. Fecal coliform for each sampling sites.

\section{B. Water quality status of Cibanten river}

Water quality management refers to the STORET method can give suggestion assessing the water quality and take action to improve water quality when quality decreasing occurs due to water pollutants.[11] The assessment of river water quality based on STORET method shows that the water quality of the Cibanten river in moderately polluted. Industrial waste seems to be the main source of pollutants, especially in developing countries like Indonesia. Urbanization leads to overpopulated growth, which is the main contributor to water pollution. The organic waste discharged from factories may contain a variety of chemical substances, as in raw sewage, interrupting the ecosystem food chain of the river and expected to be the reason for water quality indices. [12,13] Thus, chemical and organic waste from factories must be treated before being discharged to the rivers. However, it is feasible to irrigate agricultural land according to the government regulation which categorized the river water quality as $2^{\text {nd }}$ class water. (See table 3).

TABLE III. WATER QUALITy STATUS OF CiBANTEN RIVER

\begin{tabular}{ccc}
\hline Location & Score & Status \\
\hline Pabuaran village & -18 & Moderately polluted \\
Telaga kencana & -20 & Moderately polluted \\
Sumber mulya abadi & -20 & Moderately polluted \\
Kampung serut & -20 & Moderately polluted \\
Kaujon bridge & -20 & Moderately polluted \\
Kaibon bridge & -20 & Moderately polluted \\
\hline
\end{tabular}

\section{Equations}

The equations are an exception to the prescribed specifications of this template. You will need to determine whether or not your equation should be typed using either the Times New Roman or the Symbol font (please no other font). To create multileveled equations, it may be necessary to treat the equation as a graphic and insert it into the text after your paper is styled.

\section{CONCLUSION}

It can be concluded that all the monitoring stations in the Cibanten river is not recommended to be used as drinking water. However, it is feasible to irrigate agricultural land according to the government regulation which categorized the river water quality as $2^{\text {nd }}$ class water. In some situations, even stricter requirements and policies are necessary to achieve sustainability of water quality and ecology in Banten Province. 


\section{REFERENCES}

[1] Water quality report in Banten Province 2017.

[2] Baherema, Suprihatin, N.S Indrasti. "Management strategy of cibanten river banten province based on the analysis of total maximum daily loads and assimilation capacity". Journal of Natural Resources and Environtment Management.Vol. 4 No. 1: 60-69. July 2014.

[3] Z Yuan, X Wen, F Chen, Y Lin, H Zhu, F Yuan, D Kuang, and Z Jia. "Microbial indicators and their use for monitoring drinking water quality-a review”. Sustainability 2020, 12, 2249.March 2020.

[4] L. Paruch, A.M Paruch, H.G Eiken and R.Sørheim "Faecal pollution affects abundance and diversity of aquatic microbial community in anthropozoogenically influenced lotic ecosystems". Scientific Reports, (2019) 9:19469.

[5] A.E Onyango, M.W Okoth, C.N Kunyanga, B. Ochieng, O.B Aliwa. "Microbiological quality and contamination level of water sources in Isiolo County in Kenya". Journal of Environmental and Public Health. Volume 2018, Article ID 2139867, 10 pages. July 2018.

[6] V.Marie, J.Lin."Microbial indicators and environmental relationships in the Umhlangane river, durban, South Africa". Open Life Sci. 2018; 13: 385-395.

[7] Y.K Kalkhajeh, B.J Amiri, B. Huang, A.H Khalyani, W. Hu, H. Gao, M.L Thompson. "Methods for sample collection, storage, and analysis of freshwater phosphorus". Water 2019, 11, 1889. September 2019.
[8] S.S, Leong, J Ismail, N.A Denil, S.R. Sarbini, W.Wasli and A. Debbie "Microbiological and physicochemical water quality assessments of river water in an industrial region of the Northwest Coast of Borneo. Water 2018, 10, 1648. July 2018.

[9] J.S Kumar, P. Rajasekaran, N. Saran, P.S Kumar, J.P Chandran."Analysis of various water samples for enterobacteriaceae by MPN method". A Journal of Biotechnology. RRJoB (2013) 8-16. 2013.

[10] Government Regulation No. 82 of 2001 concerning management of water quality and water pollution control.

[11] I. Sulthonuddin, D.M Hartono, S.W Utomo, C.A.A Said. "Water quality assessment of cimanuk river in west java using STORET method. OP Conf. Series: Earth and Environmental Science 239 (2019) 012007.February 2019.

[12] N. Ferronato, V. Torretta. "Waste mismanagement in developing countries:a review of global issues". Int. J. Environ. Res. Public Health 2019, 16, 1060. March 2019.

[13] S. Behmel, M. Damour, R. Ludwiq, M.J Rodriguez. "Water quality monitoring strategies.A review and future perspectives". Sci. Total Environ. 2016, 571,1312-1329. June 2016. 